\title{
Partial replacement of corn by Euterpe precatoria feeding pigs raised in the Amazon
}

\author{
Substituição parcial de millho por semente de Euterpe precatoria na alimentação de suínos criados
} no Amazonas

\section{Sustitución parcial de maíz por Euterpe precatoria alimentar a los cerdos criados en el Amazonas}

Idalécio Pacífico da Silva

ORCID: https://orcid.org/0000-0001-8542-6825 Instituto Federal de Educação, Ciência e Tecnologia do Amazonas, Brazil

E-mail: pacificovet@gmail.com

Suziane Ghedini Martinelli

ORCID: https://orcid.org/0000-0002-3416-3102 Instituto Federal de Educação, Ciência e Tecnologia do Amazonas, Brazil

E-mail: suzimartinelli@yahoo.com.br

Clêirisson Ferreira de Silveira

ORCID: https://orcid.org/0000-0002-4131-6488 Instituto Federal de Educação, Ciência e Tecnologia do Amazonas, Brazil

E-mail: silvercleirisson@gmail.com

Marco Antônio Ritter

ORCID: https://orcid.org/0000-0001-5007-3417 Instituto Federal de Educação, Ciência e Tecnologia do Amazonas, Brazil E-mail: marco.rittes@ifam.edu.br

Heleno Alexandrino de Lima Filho

ORCID: https://orcid.org/0000-0003-4056-3492 Instituto Federal de Educação, Ciência e Tecnologia Goiano, Brazil

E-mail: heleno.alexandrino@ifgoiano.edu.br

Lenilton Alex de Araujo Oliveira

ORCID: https://orcid.org/0000-0002-1072-7997 Instituto Federal de Educação, Ciência e Tecnologia do Rio Grande do Norte, Brazil E-mail: fabricio.nilo@ifpa.edu.br

Fabricio Nilo Lima da Silva

ORCID: https://orcid.org/0000-0002-6402-0540 Instituto Federal de Educação, Ciência e Tecnologia do Pará, Brazil E-mail: fabricio.nilo@ifpa.edu.br

\begin{abstract}
The objective was to evaluate the potential of using Euterpe precatoria Mart seed to feed pigs. Diets were prepared with different levels of inclusion of açaí seed $(0 ; 7.5 ; 15$ and $22.5 \%)$, resulting from the extraction of the stern. Forty four castrated weighing approximately $15 \mathrm{~kg}$ and average 60 days of birth pigs were used, distributed in four groups according to the level of inclusion of açaí kernel. After 56 days of feeding, the pigs' performance and economic viability were evaluated. There was no significant difference in daily feed intake, final weight, weight gain and feed conversion between groups of treatments to the statistical test. The inclusion of up to $22.5 \%$ of açaí kernels in the diet did not result in a statistical difference in the thickness of backfat, percentage of lean meat and carcass yield, however it increased the gross and partial net revenue and the economic viability in the test, demonstrating the potential from açaí seed for the production of slow-growing crossbred pigs in the Amazon region, especially in properties that exploit the sustainable extraction of açaí and that can reduce the impact of the fruit residue on the environment when using this by-product in animal feed. Reducing production costs and allowing the promotion of sustainable development in the Amazon region.
\end{abstract}

Keywords: Agroindustrial residue; Alternative feed; Sustainability; Euterpe precatoria mart.

\section{Resumo}

Objetivou-se pela primeira vez avaliar o potencial da utilização da semente de Euterpe precatoria Mart na alimentação de suínos. Foram elaboradas rações com diferentes níveis de inclusão de semente de açaí $(0 ; 7,5 ; 15$ e $22,5 \%$ ), resultante da extração da polpa. Foram utilizados 44 suínos castrados, pesando aproximadamente $15 \mathrm{~kg}$ e média de 60 dias de nascimento, distribuídos em quatro grupos de acordo com o nível de inclusão de semente de açaí. Após 56 dias de alimentação, foi avaliado o desempenho dos suínos e a viabilidade econômica. Não houve diferença significativa no consumo diário de ração, no peso final, ganho de peso e conversão alimentar entre os grupos de tratamentos ao teste estatístico. A inclusão até $22,5 \%$ de semente de açaí na ração não resultou em diferença estatística na espessura de toucinho, porcentagem de carne magra e rendimento de carcaça, no entanto incrementou a 
receita bruta e líquida parcial e a viabilidade econômica no teste, demonstrando o potencial do caroço de açaí para a produção de suínos de crescimento lento na região Amazônica, especialmente nas propriedades que exploram a extração sustentável de açaí e que podem reduzir o impacto do resíduo do fruto no ambiente ao utilizarem este subproduto na alimentação animal. Reduzindo os custos de produção e permitindo a promoção do desenvolvimento sustentável na região amazônica.

Palavras-chave: Resíduo agroindustrial; Alimento alternativo; Sustentabilidade; Euterpe precatoria mart.

\section{Resumen}

El objetivo era evaluar el potencial del uso de semillas de Euterpe precatoria Mart para alimentar a los cerdos. Se prepararon dietas con diferentes niveles de inclusión de semilla de açaí ( $0 ; 7.5 ; 15$ y 22.5\%), como resultado de la extracción de la popa. Se utilizaron 44 cerdos castrados, con un peso aproximado de $15 \mathrm{~kg}$ y un promedio de 60 días de nacimiento, distribuidos en cuatro grupos según el nivel de inclusión del grano de açaí. Después de 56 días de alimentación, se evaluó el rendimiento y la viabilidad económica de los cerdos. No hubo diferencias significativas en la ingesta diaria de alimento, el peso final, el aumento de peso y la conversión alimenticia entre los grupos de tratamientos para la prueba estadística. La inclusión de hasta un $22.5 \%$ de granos de açaí en la dieta no resultó en una diferencia estadística en el grosor de la grasa, el porcentaje de carne magra y el rendimiento de la canal, sin embargo, aumentó el ingreso neto bruto y parcial y la viabilidad económica en la prueba , demostrando el potencial de la semilla de açaí para la producción de cerdos mestizos de crecimiento lento en la región amazónica, especialmente en propiedades que explotan la extracción sostenible de açaí y que pueden reducir el impacto del residuo de fruta en el medio ambiente cuando se usa este subproducto en alimentación animal. Reducir los costos de producción y permitir la promoción del desarrollo sostenible en la región amazónica.

Palabras clave: Residuos agroindustriales; Comida alternativa; Sustentabilidad; Euterpe precatoria mart.

\section{Introduction}

The açaí tree (Euterpe precatoria Mart.) stands out for its abundance and for producing important food for the populations in the Amazon region. According to IBGE (2017), Amazonas produces 21,729 tons of the fruit. The wine from the processing of the fruit pulp is the main source of food for many locals. Research shows that the seeds, as a by-product obtained in the extraction of the pulp, correspond to about $90 \%$ of the total weight of the fruits and can be used in animal feed (Guimarães and Storti Filho, 2004; Gomes et al., 2012; Arruda et al., 2018), especially in circumstances where an attempt is being made to increase the participation of fiber in the diet (Townsend et al., 2001).

Swine production systems present barriers related to the sustainability of productive models. For Figueiredo and Soares (2012) it is necessary to use zootechnical practices that maximize animal welfare, the quality of the product produced and the economic return of non-intensive systems, so that they produce properly without the use of inputs external to the property and without harm their health and well-being. In this context, research on nutrition seeks alternative ingredients that combine affordable price, continuous supply and guarantee good levels of animal efficiency (Moreira et al., 2013).

In view of this scenario, studies with alternative foods are being carried out with the purpose of enabling the use in the swine diet, according to each category, constituting a regionalized option with reduction of production costs and benefiting producers and animals. However, most alternative feeds require in-depth studies from the scientific community that accurately determine their participation in meeting the nutritional requirements of swines (Gomes et al., 2007).

Alternative foods, such as barley, cassava, triticale and sorghum can replace corn in diets, without reducing the performance of pigs, and may reduce the cost of feed (Figueiredo et al., 2012; Woyengo et al., 2014). With a view to use in animal feed, Townsend et al 2001 determined the chemical-bromatological characteristics of the açaí seed and found that Dry Matter remained close to $64 \%$ and the Crude Protein content fluctuated between 4.0 and 5.3\%. The use of açaí seed, a byproduct obtained in the preparation of the pulp, in animal feed, has aroused the interest of several producers, in certain cases it has been taking place empirically. This work was carried out with the objective of evaluating for the first time the performance of the partial inclusion of açaí seeds in the feeding of swines in the growing phase raised in Amazonia. 


\section{Methodology}

The study was carried out at the Animal Production Sector of the Federal Institute of Amazonas (IFAM), in the city of Lábrea (AM), with a Monsoon Tropical Climate, located in the South of Amazonas, Northern Brazil, Altitude (m): 61, Latitude: $7^{\circ} 0$ 'S, Longitude: $64^{\circ} 0$ 'W. The region has a high rainfall index, with concentration from October to May.

Samples of açaí seeds were collected from agroextractive producers in the municipality of Lábrea-AM. After extracting the pulp from the açaí fruit, weighing and proximate analysis were carried out, allowing the ingredients to be balanced in the feed. After gathering and weighing, the samples were separated into identified packages, kept in a freezer ($18^{\circ} \mathrm{C}$ ) and later sent to the laboratories.

The samples were sent to the Animal Bromatology Laboratory of the Federal University of Santa Maria Campus Palmeira das Missões, for analysis of dry matter (DM), mineral matter (MM) and crude protein (CP) (Micro-Kjeldahl) following the methods described by AOAC (1995), fat (EE) by Bligh and Dyer (1959), neutral detergent fiber (NDF) and acid detergent fiber (ADF) by the method of Van Soest et al., (1991). Another part of the samples was sent to the Laboratory of Bromatology and Nutrition of Ruminants, at the Federal University of Santa Maria, where the anti-nutritional factors were analyzed: phenolic compounds, total and condensed tannins, following Makkar's methodology (2000).

All samples were analyzed in triplicate and the data were compiled and presented in a table format, containing the chemical composition of the açaí seed and the percentage of antinutritional factors.

The swine performance test was carried out at the Federal Institute of Amazonas (IFAM)/ Campus Lábrea (AM). A number of 44 swine from the Piau breed (Sus scrofa) were used. They were castrated males weighing approximately $15 \mathrm{~kg}$ and average 60 days of birth, raised under strict sanitary management and belonging to IFAM's farm. The animals were kept in facilities equipped with a concrete feeder and a nipple-type drinker appropriate to the species and the life stage. The pigs received healthy nutrition in an adequate amount for their development.

The feed was available and easily accessible for each animal where it was offered in always clean feeders in which all animals could feed at the same time to avoid competition for feed. They had access to clean, fresh, and abundant drinking water. The facilities on which the animals were raised had no protrusions or sharp edges to prevent injury. The material on the inner surface of the pens is easy to clean and disinfect to help prevent swine diseases. The design of the facilities used in the experiment provided the appropriate environment to protect animals from excessive cold or heat, allowing sufficient ventilation for gas exchange and that the humidity is not high. It also contained adequate space for a resting area: dry and comfortable, with enough available floor for free movement with freedom to keep the animals in well-being.

Everyone involved in the experiment received handling training for animal welfare so that the animals were treated with tranquility and calm, with the aim of making the pigs accustom to human contact, so that they are not afraid or suffer stress when get in touch with humans. The experimental plots were distributed among four experimental groups with eleven repetitions and received feed with increasing levels of açaí seed: treatment 0 ( $0 \%$ of açaí seed); treatment 7.5 (7.5\% of açaí seed); treatment 15 (15\% of açaí seed) and treatment 22.5 (22.5\% of açaí seed). The animals were submitted to an adaptation period of 10 days. The açaí seed was crushed, added to the feed and made available in two daily portions to the animals.

Isoproteic feed was formulated (Table 1) according to the nutritional levels recommended for the production phase according to Rostagno et al. (2011), based on corn bran, soy bran, vitamins and minerals, with and without the addition of açaí seed. 
Table 1. Centesimal Composition*.

\begin{tabular}{lcccc}
\hline \multicolumn{4}{c}{ Levels of inclusion of açaí's seed (\%) } & \multicolumn{1}{c}{ (5 } \\
\hline & 0 & 7.5 & 15.00 & 22.50 \\
\hline Açaí seed \% & 0.00 & 7.50 & 22.50 & 23.35 \\
Soy Bran \% & 20.84 & 21.67 & 58.85 & 50.50 \\
Corn Bran \% & 75.51 & 67.18 & 0.30 & 0.30 \\
Soy Oil \% & 0.30 & 0.30 & 2.00 & 2.00 \\
Calcitic limestone \% & 2.00 & 2.00 & 0.35 & 0.35 \\
Salt \% & 0.35 & 0.35 & 1.00 & 1.00 \\
Premix Mineral Vit. ${ }^{1}$ & 1.00 & 1.00 & 100.00 & 100.00 \\
Total & 100.00 & 100.00 & & 15.68 \\
Calculated composition* & & & 15.68 & 2.91 \\
Crude protein & 15.68 & 15.68 & 3.07 & 2.370 \\
Ethereal Extract & 3.37 & 3.22 & 2.309 & 25.874 \\
Mineral Matter & 2.189 & 2.249 & 21.169 & 3957.347 \\
FDN & 11.761 & 16.465 & 3918.088 & 0.851 \\
Gross Energy & 3839.631 & 3878.859 & 0.845 & 0.380 \\
Calcium & 0.833 & 0.839 & 0.385 & 2.241 \\
Available Phosphorus & 0.395 & 0.390 & 2.197 & \\
Ca: P Ratio & 2.110 & 2.153 & & \\
\hline
\end{tabular}

${ }^{1}$ Quantity per kg of product: vit. A 500,000 IU, vit. B1 1,200 mg, Vit. B2 2,000 mg, Vit B6 2,300 mg, Vit. D 100,000 IU, vit. K 600mg, niacin 3,000mg, pantothenic acid 2,500mg, folic acid $7 \mathrm{mg}$, choline $5.00 \mathrm{mg}$, methionine $10 \mathrm{~g}$, calcium $215 \mathrm{~g}$, copper $450 \mathrm{mg}$, iron $2.750 \mathrm{mg}$, phosphorus $85 \mathrm{mg}$, fluorine $850 \mathrm{mg}$, iodine $17.5 \mathrm{mg}$, manganese $1.250 \mathrm{mg}$, selenium $7.5 \mathrm{mg}$, sodium $49 \mathrm{mg}$, zinc $2,750 \mathrm{mg}$, chromium $5 \mathrm{mg}$, zinc bacitracin 1,000mg. * Values proposed by Rostagno et al. (2011).

Animal weight, daily feed intake (FI), weight gain (WG) and feed conversion (FC) were measured on day 0 and every 14 days until the end of the experiment, at 56 days of treatment.

At the end of the treatment, the animals were subjected to a solid fasting of 15 hours, weighed and slaughtered with sanitary inspection. Pre-slaughter management was necessary to mitigate stress. The pigs remained in a covered resting area, with ventilation, and permanent availability of drinking water so that there is a reduction in thermal stress due to heat. In order for the animals to be bled, they were first stunned by electronarcosis. The stunning consisted of leaving the animal in a state of unconsciousness that persisted until bleeding, avoiding suffering and capable of promoting complete bleeding. The carcasses were sawn lengthwise and weighed, finally obtaining the characteristics of the carcasses to compose the study of economic viability. Were collected data on the mean fat thickness (FT), resulting from the fat thickness at the height of the first and last thoracic vertebrae and the last lumbar vertebrae, loin depth (LD), between the last and penultimate rib, $6 \mathrm{~cm}$ from the dorsal midline, in the right half-carcass and hot carcass weight (HCW), without legs and head, according to Bridi and Silva (2009).

The cost of food was determined from the total feed consumption of each animal during the experimental period and the value of each ingredient contained in the diet. The amounts paid to the constituent ingredients of the diets were $\mathrm{R} \$ 0.91 / \mathrm{kg}$ of corn bran; $\mathrm{R} \$ 2.338 / \mathrm{kg}$ of soy bran $45 \%$; $\mathrm{R} \$ 3.0 /$ Soy oil; $\mathrm{R} \$ 20 / \mathrm{kg}$ of vitamin and mineral premix; $\mathrm{R} \$ 0.68 / \mathrm{kg}$ of salt; $\mathrm{R} \$$ $1.8 / \mathrm{kg}$ of calcitic limestone.

The percentage of lean meat (\% LM) in the carcass was calculated according to the following equation (Guidoni, 2000): \% LM $=65.92-0.685 *(\mathrm{ET}=$ fat thickness $)+0.094 *(\mathrm{LD}=$ loin depth $)-0.026 \times(\mathrm{HCW}=$ hot carcass weight $)$. The amount paid per kilo of live swine in the region at the beginning of the experiment was $R \$ 3.50$. To determine the value of the final swine, the following equation was used: Final Swine $(\mathrm{R} \$)=$ final weight $\mathrm{x}$ carcass $\mathrm{kg}$ price. The initial value of swine $(\mathrm{R} \$)$ = initial weight $\mathrm{x}$ price of the $\mathrm{kg}$ of the live Swine. 
Partial gross and net revenue were calculated using the equations: Partial gross revenue $(\mathrm{PGR})=$ final swine - initial swine and Partial net revenue $(\mathrm{PNR})=$ PGR - cost of feed, respectively.

The performance and economic viability data were subjected to the normality test, analysis of variance and polynomial regression at 5\% significance using the SAS v.9.1 statistical program. When data were not adjusted to the polynomial regression models, they were compared using the Tukey test $(\mathrm{P}<0.05 \%)$.

The procedures involving the animals in this study are in accordance with the Ethics Committee on the Use of Animals - CEUA - Protocol No. 029.01.0000.0606 / 2018.

\section{Results and Discussion}

Table 2 shows the results of the chemical-bromatological analysis of the açaí seed.

Table 2. Bromatological Composition of açaí seed (Euterpe precatoria Mart).

\begin{tabular}{llllllllllll}
\hline \multicolumn{10}{c}{ Centesimal Composition of açaí seed (\%) } \\
\hline DM & MM & RP & EE & NDF & ADF & Lig & Hem & Cel & Fen & Ta & CT \\
85,83 & 1,79 & 4,12 & 1,56 & 74,24 & 26,66 & 5,87 & 47,58 & 20,79 & 0,27 & 0,14 & 0,01 \\
\hline
\end{tabular}

DM: dry matter; MM: mineral matter; CP: crude protein; EE: ethereal extract; NDF: neutral detergent fiber; FDA: acid detergent fiber; Lig: lignin; Hem: hemicellulose; Cel: cellulose; Fen: Total phenols; Ta: Tannins in dry matter; CT: Condensed Tannins. Source: Authors.

Seed DM remained close to $85 \%$. The CP content was $4.12 \%$, remaining below the level considered as a minimum limit for animal species of zootechnical interest (Rostagno et al., 2011).

The high levels of fiber (NDF + ADF) and lignin in seed açai were also described by Altman (1956), results similar to those obtained by Rodrigues Filho et al. (1993), both analyzing the species Euterpe oleraceae. Most alternative foods are waste from industry, with high levels of fiber, which requires in-depth studies from the scientific community that accurately determine the role of fiber in the nutrition of monogastrics (Gomes et al., 2012). However, poultry and pigs use the fibrous fraction of food as an energy source (from 5 to $30 \%$ of maintenance energy) (NRC, 1998).

The presence of minerals is relatively low (1.56).These results, therefore, reveal the low nutritional value of açaí seed for monogastric, which would make it limited to use this by-product in the feeding of high-performance lineage animals.

As for the contents of phenols and tannins (total and condensed), there is a low concentration of these compounds in the açaí seed, which is a positive point since the tannin negatively affects the nutritional quality of food, can cause a reduction in the intake of DM, binding with food protein. and formation of complexes with digestive enzymes (Cordão et al., 2010).

According to Cunha et al. (2012) the chemical composition can vary according to the fruit species, harvest period, soil type and fertilization, location and climatic condition of the plantation site and differences in the extraction of the pulp, amount of water, time and temperature during the extraction of the pulp. It is therefore important to evaluate the composition of each sample to be used in feed formulations.

\section{Animal performance test}

The swine trial showed no significant difference in final weight, weight gain and feed conversion between the treated groups up to $22.5 \%$ of inclusion of açaí seed in the diet (Table 3). 
Table 3. Average performance values of growing swine fed diets containing levels of açaí seed instead of corn.

\begin{tabular}{lccc}
\hline \multirow{2}{*}{ Treatment } & \multicolumn{3}{c}{ Parameters } \\
\cline { 2 - 4 } & FW & WG & FC \\
\hline $7.5 \%$ & $32.00 \pm 2.82$ & $16.23 \pm 1.15$ & $3.12 \pm 0.19$ \\
$15 \%$ & $30.64 \pm 2.33$ & $14.77 \pm 1.37$ & $4.58 \pm 1.49$ \\
$22.5 \%$ & $30.68 \pm 1.56$ & $15.23 \pm 0.59$ & $3.25 \pm 0.15$ \\
\hline
\end{tabular}

$* 0 \%=$ Feed without inclusion of açaí seed; $7.5 \%=$ Feed with inclusion of $7.5 \%$ of açaí seed; $15 \%$ = Feed with $15 \%$ inclusion of açaí seed; $22.5 \%=$ Feed with inclusion of $22.5 \%$ of açaí seed; FW = Final weight $(\mathrm{Kg})$; WG = Weight gain $(\mathrm{Kg}) ; \mathrm{FC}=\mathrm{Feed}$ conversion $(\mathrm{FC}=$ Consumption/Weight gain). Expressed values \pm standard error of the mean. Means followed by different letters in the columns differ from each other by the Tukey test $(\mathrm{P}<0.05)$. Source: Authors.

Our results demonstrate that the pigs tested showed no change in performance to performance test the inclusion of the açai seed, confirming its potential as an alternative to corn in the diet. The potential of açaí seed was also previously evaluated with other species of zootechnical interest. Arruda et al. (2018), tested the inclusion of açaí seed bran in the colonial chicken diet in the proportion of up to $10 \%$ in the initial phase without impact on performance. They also stated that the use of diets containing $10 \%$ of açaí seed is in fact a viable alternative for the production and the reduction of the negative impacts generated by the residues on the environment.

Gomes et al. (2012) evaluated the inclusion of açaí seed in ruminant diets and obtained satisfactory results in the inclusion of up to $15 \%$ in the sheep diet. Guimarães and Storti Filho (2004) evaluated the performance of tambaquis fed with açaí seed and shell, as the main alternative product after the use of the pulp. They concluded that several products added to the diet can serve as a basis for the elaboration of supplementary diets.

Therefore, it is worth remembering that the swine is an omnivorous animal and that its natural food consists of a wide variety of foods - pasture, branches, roots, insects, earthworms, small animals, grains and many others. And this has been the natural diet of swines for millions of years and for which the digestive system of this species is adapted (Machado Filho et al., 2001). It should also be noted that pigs have high capacity to adapt the morphology and flora of the gastrointestinal tract to fibrous diets (Teixeira, 1995). There is, therefore, a great potential for the incorporation of fiber and by-products in diets for pigs, with a productive and economic advantage (Close, 1994).

\section{Analysis of carcass characteristics}

Table 4 shows the average values of hot carcass weight, carcass yield, percentage of lean meat, loin depth and backfat thickness, according to percentage of inclusion of açaí seed.

Table 4. Average values of the effect of açaí seed on the variables of the study of the carcass characteristics of swines.

\begin{tabular}{lcccc}
\hline \multirow{2}{*}{ Variable } & \multicolumn{4}{c}{ Inclusion of açaí seed } \\
\cline { 2 - 5 } & 0 & $7,5 \%$ & $15 \%$ & $22,5 \%$ \\
\hline Hot carcass weight (kg) & $23.33 \pm 0.17$ & $22.83 \pm 0.44$ & $22.83 \pm 0.73$ & $22.16 \pm 1.09$ \\
Carcass yield (\%) & $66.51 \pm 0.42$ & $66.51 \pm 1.33$ & $67.16 \pm 2.13$ & $64.07 \pm 3.99$ \\
Lean meat (\%) & $59.16 \pm 0.97$ & $59.11 \pm 1.11$ & $57.57 \pm 0.36$ & $58.05 \pm 0.29$ \\
Loin depth (mm) & $39.00 \pm 0.57$ & $38.33 \pm 1.20$ & $41.33 \pm 0.66$ & $39.00 \pm 1.00$ \\
Backfat thickness (mm) & $14.33 \pm 1.45$ & $14.33 \pm 1.45$ & $17.00 \pm 0.58$ & $16.00 \pm 0.58$ \\
\hline
\end{tabular}

HCW: hot carcass weight; CY: carcass yield; \%LM: percentage of lean meat; LD: loin depth and BT: backfat thickness. Expressed values \pm standard error of the mean. Source: Authors. 
The results show that there was no significant effect of the inclusion of increasing levels of açaí seeds on the parameters of the carcass characteristics analyzed. These results demonstrate the ability of swine to use the fibers in their food to meet their energy requirements. According to Oliveira et al. (2007), the colon and cecum regions of the swine gastrointestinal tract have characteristics that favor the growth of fiber-fermenting bacteria. For Noblet and Le Goff (2001), the most known predominant bacteria present in these regions that degrade cellulose, hemicellulose and pectin, are the Bacteroides succinogenes and Ruminococcus flavefaciens, Bacteroides ruminicola and Ruminococcus albums. These microorganisms act through the fiber fermentation process. Therefore, cellulose, hemicellulose and pectin are degraded to short-chain volatile fatty acids (AGVs), such as acetate, propionate and butyrate (Willians et al., 2001).

Watanabe et al. (2009) tested the inclusion of up to $30 \%$ of the citrus pulp in the diets of finishing swines and observed a linear reduction in the Loin Depth and Hot Carcass Weight. With the increase in the percentage of citrus pulp, however, such decrease was not enough to affect the percentage of lean meat. In addition, there is no reduction in the Thickness of backfat and, in this way, the quality of the swine carcass at 130kg has not improved.

Given this scenario, studies with alternative foods are being carried out with the purpose of making their use in the swine diet feasible, according to each category, constituting a regionalized option with reduced production costs and benefiting the production system and the environment. However, most alternative feeds are waste from industries, with high levels of fiber, which requires studies that accurately determine the role of fiber in the nutrition of monogastrics, especially in relation to their participation in meeting the nutritional requirements of swine (Gomes et al., 2007).

\section{Economic feasibility of including açaí seed}

Table 5 shows data related to feed costs, partial gross revenue and partial net revenue, depending on the percentage of inclusion of açaí seeds.

The addition of açaí seed to the diet resulted in reduced feed costs. A negative linear effect was observed $(\mathrm{P}=0.05)$ due to the proportion of inclusion of the seed (Figure 1) compared to the costs of the base ration (Table 5), (corn, soybean bran and other feed ingredients) observed during the experimental period. There was also a linear increase in partial gross revenue and partial net revenue $(\mathrm{P}<0.05)$, due to the inclusion of açaí seed in comparison with the quotations of the feed ingredients and the swine (Figure 2). 
Table 5. Average values of the effect of açaí seed on the variables of the study of the economic viability of slaughtered swines.

\begin{tabular}{lcccc}
\hline & \multicolumn{4}{c}{ Treatments } \\
\cline { 2 - 5 } \multicolumn{1}{c}{ Variables } & 0 & 7.5 & 15.0 & 22.5 \\
\hline ILW $(\mathrm{kg})$ & $15.83 \pm 0.33$ & $15.86 \pm 0.17$ & $15.45 \pm 0.27$ & $15.27 \pm 0.13$ \\
FLW (kg) & $34.33 \pm 0.33$ & $34.50 \pm 0.28$ & $34.00 \pm 0.00$ & $35.00 \pm 0.50$ \\
FC (kg) & $44.50 \pm 0.00$ & $44.50 \pm 0.00$ & $44.50 \pm 0.00$ & $44.50 \pm 0.00$ \\
PGR (R\$)* & $118.37 \pm 0.12$ & $118.27 \pm 1.98$ & $122.09 \pm 2.09$ & $123.05 \pm 0.70$ \\
PNR (R\$) & $49.14^{\mathrm{c}} \pm 0.12$ & $51.80^{\mathrm{bc}} \pm 1.98$ & $58.37^{\mathrm{b}} \pm 2.09$ & $62.09^{\mathrm{a}} \pm 0.70$ \\
FV (R\$)/kg & $1.43^{\mathrm{a}} \pm 0.00$ & $1.37^{\mathrm{b}} \pm 0.00$ & $1.31^{\mathrm{c}} \pm 0.00$ & $1.26^{\mathrm{d}} \pm 0.00$ \\
CPA $(\mathrm{R} \$) / \mathrm{cab}$ & $69.23^{\mathrm{a}} \pm 0.00(100)$ & $66.47^{\mathrm{b}} \pm 0,00(-4.20)$ & $63.71^{\mathrm{c}} \pm 0.00(-8.39)$ & $60.96^{\mathrm{d}} \pm 0.00(-11.89)$ \\
\hline
\end{tabular}

ILW: Initial live weight; FLW: final live weight; FC: feed consumption; PGR: partial gross revenue; PNR: partial net revenue; FV: feed value; PCF: partial cost with food. Different letters on the same line indicate a significant difference $(\mathrm{P}<0.05)$ by the Tukey test. Expressed values \pm standard error of the mean. Source: Authors.

Figure 1. The cost of the feed and partial cost of food for the experimental period of October of November 2018, according to the percentage of inclusion of açaí seed pulp in the pig diet.
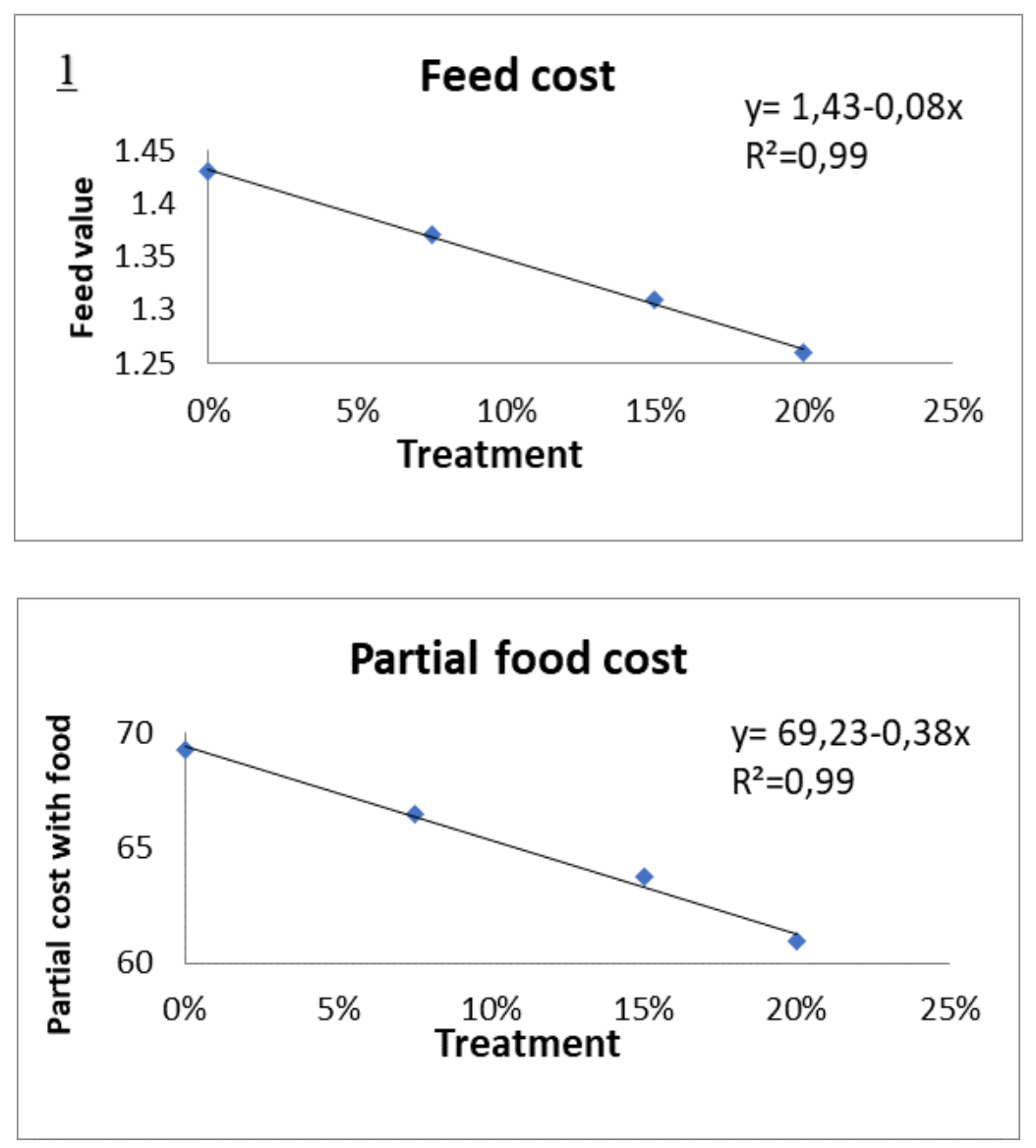

Source: Authors. 
Figure 2. Partial gross and partial net revenue from the October to November 2018 trial period, depending on the percentage of inclusion of açaí pulp in the swine diet.
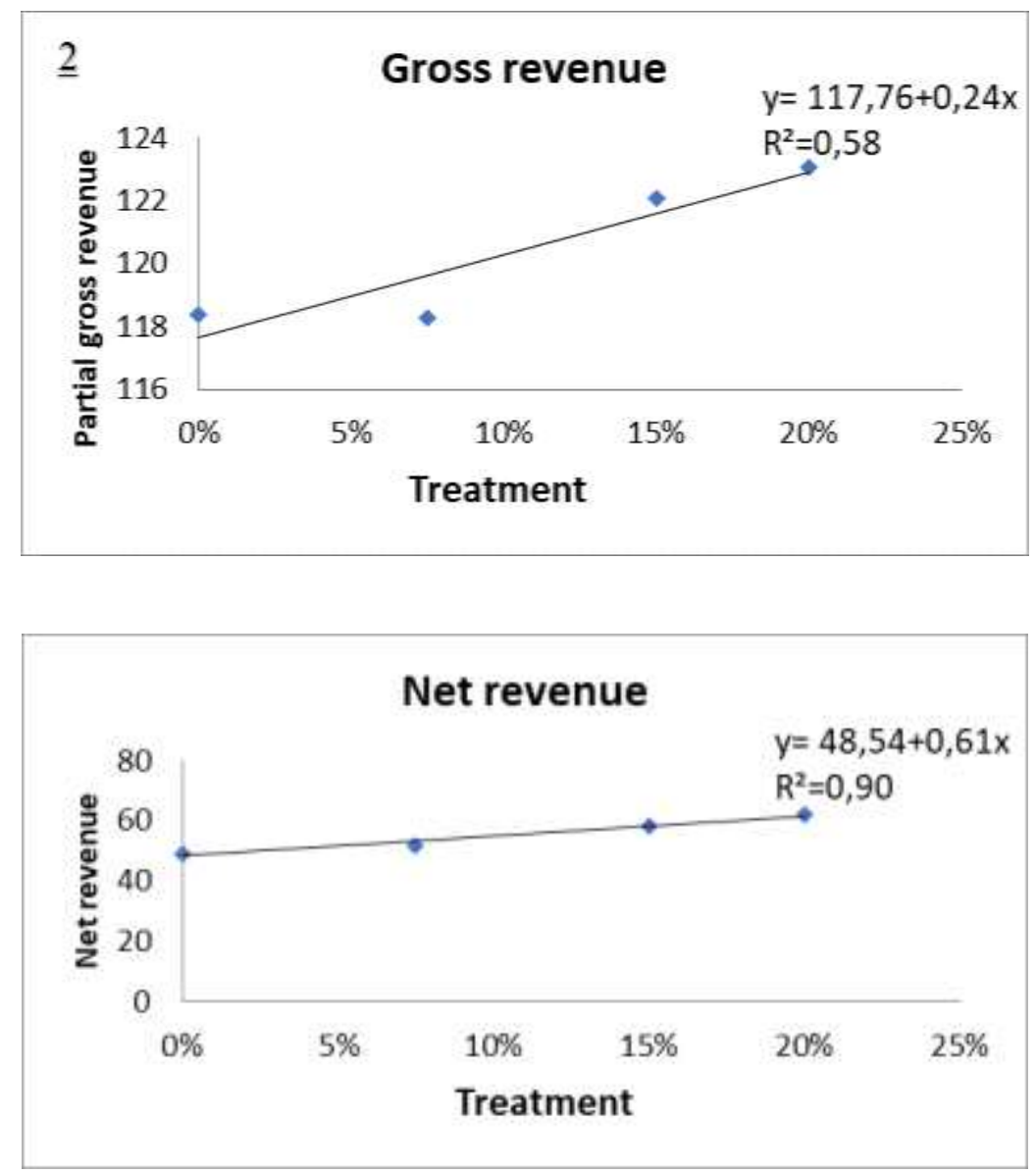

Source: Authors.

In this work, the açaí seed had no acquisition cost, as this by-product is discarded in the environment as industrial waste. As a result, the biggest difference observed between the price of the base ration and the inclusion of açaí seed was $\mathrm{R} \$$ 0.17 , which represents an $11.89 \%$ reduction in the partial cost of food (Table 5), which is sufficient to increase the gross and partial net revenue from swine production. For Fraga (2005), the price of the kilogram of corn is the factor most related to the profitability of alternatives diets, the greater the economic viability of its use the greater the difference between the price of corn and the alternative ingredient.

The costs of the ingredients of the diets to be used and the sale value of the pigs can be limiting for the adoption of alternative foods, For Watanabe et al. (2009), working with qualitative feed restriction of finishing swine, concluded that the costs of the ingredients to be used can be limiting for the adoption of alternative diets. Like Fraga (2005) who found an increase in gross revenue due to the effect of qualitative feed restriction due to the improvement of the bonus index, evaluating the inclusion of rice husk in the swine diet.

Alternative foods can replace corn in diets, without significantly reducing the performance of swine, which can lower the cost of feed (Woyengo et al., 2014), as well as reducing the impacts arising from the improper release of co-products from industry in the environment (Silva et al., 2017). Thus, the use of by-products found locally, require in-depth studies in order to meet nutritional requirements, minimize barriers due to high prices of commercial feed, considering the cost reduction and anti-nutritional factors present in vegetables (Silva et al., 2017). A peculiar characteristic of the region is the difficult land access throughout the year, which increases the cost of transportation and acquisition of agricultural inputs, making the 
production process of animal production close to financial unfeasibility, especially in family farming.

From an environmental point of view, the inclusion of açaí seeds in swine feed contributes to the sustainability of the açaí production chain in northern Brazil, in addition to reducing the environmental impact generated by the accumulation of açaí residues in nature. According to Filho et al. (2001), it is a condition of agroecology and implies minimizing or even eliminating the use of inputs from chemical synthesis processes.

Thus, the agroecological breeding of swine has been an alternative for small production, as it has lower costs, less capital invested, and generates a product of greater value, as it is superior to conventional production in environmental, energy and animal welfare terms with less dependence on external inputs and less social and cultural impact, therefore, it must be competitive also economically.

Diets with increasing levels of açaí seeds had lower costs compared to the standard diet $(-4.20 \%,-8.39 \%$ and $11.89 \%$, respectively, for $7.5 \%, 15 \%$ and $22.5 \%$ of inclusion of açaí seed). The price of soy bran ( $\mathrm{R} \$ 2.338 / \mathrm{kg}$ ) was an important factor in the cost of feed with increasing inclusion of açaí seed. However, even with increase in its proportion in the treatment feed for nutritional reasons, it was not enough to reflect the higher cost per kilo of swine produced with diets containing açaí seeds. This is because açaí bran can be prepared on the spot by producers at low cost, since the by-product is discarded in nature and only manual labor with the use of simple equipment is necessary for the processing of fresh seed residues.

Therefore, future studies should evaluate other parameters and dietary compositions using açaí seeds and other financially viable alternatives for smallholders resulting in economic viability in production.

\section{Conclusion}

The study contributes to the use of açaí seeds up to $22.5 \%$ in the diets of native swine raised in the Amazon region.

It also collaborates with the use of this by-product of easily acquired in the Amazon region, in addition to promoting the reduction of the negative impacts generated by the waste in nature, as it is discarded in the ambient after the pulpy extracted from the fruit.

It collaborates with the encouragement of crossbred pigs or of native breeds, which are more suitable to the region for presenting rusticity and good adaptability to the local climate.

Thus, it contributes to a more sustainable animal breeding, seeking the use of internal inputs to agro-ecosystems and preserving the biodiversity of native breeds and more adapted to the region, thus contributing to the principles of agroecological systems.

\section{Acknowledgments}

This research was supported by the Support Program for the Development of Scientific Research Applied to Technological Innovation - PADCIT / IFAM, by Campus Lábrea and by UFSM.

\section{References}

Altman, R. F. A. (1956). O caroço de açaí (Euterpe oleracea Mart.). Belém: Institudo Agronômico do Norte, 109-111. (IAN. Boletim de Pesquisa, 31).

AOAC. (1995). Association of Official Analytical Chemists. Official Methods of Analysis of AOAC, (16a ed.), Washington, DC: Patricia Cunniff (editor), $1141 \mathrm{p}$.

Arruda, J. C. B., Fonseca, L. A. B., Pinto, L. C. P., Pinheiro, H. C. O., Monteiro, B. T. O., Manno, M. C., Lima, K. R. S., \& Lima, A. R. (2018). Açaí seed bran in the feed of slow-growth broilers. Acta Amazônica, 48, 298-303.

Bligh, E. C. \& Dyer, W. J. (1959). A rapid method of total lipid. Extraction and purification. Canadian Journal Biochemistry Physiology, 37, $911-917$. 
Bridi, A. M., \& Silva, C. A. (2009). Avaliação da carne suína. Midiograf, 120p.

Close, W. H. (1994). Fibrous diets for pigs. Pig News Information, Oxon, 15, 65.

Cordão, M. A., Pereira Filho, J. M., Bakke, O. A. \& Bakke, I. A. (2010). Taninos e seus efeitos na alimentação animal - Revisão bibliográfica. Pubvet, 4(32).

Cunha, O. F. R., Neiva, J. N. M., Maciel, R. P., Miotto, F. R. C., Neiva, A. C. G. R. \& Restle, J. (2012). Avaliação bieconômica do uso da torta de dendê na alimentação de vacas leiteiras. Ciência Animal Brasileira, 13, 315-322.

Figueiredo, A. V., Albuquerque, D. M. N., Lopes, J. B., Farias, L. A., Marques, C. M. \& Carvalho Filho, D. U. (2012). Feno da rama de mandioca para suínos em terminação. Revista Brasileira de Saúde e Produção Animal, 13, 791-803.

Figueiredo, E. A. P. \& Soares, J. P. G. (2012). Sistemas orgânicos de produção animal: dimensões técnicas e econômicas. Anais... In: 49ª Reunião Anual da Sociedade Brasileira de Zootecnia: A produção animal no mundo em transformação, Brasília - DF.

Guimarães, S. F. \& Storti Filho, A. (2004). Produtos agrícolas e florestais como alimento suplementar de tambaqui em policultivo com jaraqui. Pesquisa Agropecuária Brasileira, 39, 293-296.

Gomes, D. I., Véras, R. M. L., Alves, K. S., Detmann, E, Oliveira, L. R. S., Mezzomo, R., Santos, R. B. \& Barcelos, S. S. (2012). Performance and digestibility of growing sheep fed with açai seed meal-based diets. Tropical Animal Health and Production, 44(7), 1751-1757.

Gomes, J. D. F., Putrino, S. M., Grossklaus, C., Utiyama, C. E., Oetting, L. L., Souza, L. W. O., Fukushima, R. S., Fagundes, A. C. A., Sobral, P. J. A., Lima, C. G. (2007). Efeitos do incremento da fibra dietética sobre a digestibilidade, desempenho e características de carcaça: I. suínos em crescimento e terminação. Semina: Ciências Agrárias, 28(3), 483-492.

IBGE. 2017. Instituto Brasileiro de Geografia e Estatística. SIDRA. Extração vegetal e silvicultura - 2016. http://www.sidra.ibge.gov.br. Acesso em: 04 de abril de 2019 .

Makkar, H. P. S. (2000). Quantification of Tannins in Tree Foliage. (Laboratory manual) Vienna: FAO, IAEA.

Machado Filho, L. C. P., Silveira, M. C. A. C., Hötzel, M. J. \& Machado, L. C. (2001). Produção agroecológica de suínos - uma alternativa sustentável para a pequena propriedade no Brasil. Florianópolis, UFSC.

Moreira, F. R. C., Costa, A. N., Martins, T. D. D., Silva, J. H. V., Cruz, G. R. B. \& Pascoal, L. A. F. (2013). Substituição parcial do milho por sorgo granífero na alimentação de matrizes suínas primíparas nos períodos de puberdade e gestação. Arquivo Brasileiro de Medicina Veterinária e Zootecnia, 65(3), 902-908.

Noblet, J. \& Legoff, G. (2001). Effect of dietary fibre on the energy value of feeds for pigs. Anim. Feed Sci. Technol., 90, 35-52.

National Research Council. (1998). Nutrients requirements of Swine. (10a ed.), Washington National Academic Science, 189 p.

Oliveira, S. L., Fialho, E. T., Lima, J. A. F. \& Araújo, J. S. (2007). Metabolismo do nitrogênio em suínos alimentados com dietas contendo baixos teores de proteína bruta. Revista Brasileira Agrociência, 13(2), 257-260, 2007.

Rodrigues Filho, J. A, Camarão, A. P. \& Lourenço Junior, J B. (1993). Avaliação de subprodutos agroindústrias para alimentação de ruminantes. Belém: EMBRAPA-CPATU, 15p. (EMBRAPA-CPATU. Documentos, 71).

Rostagno, H. S., Albino, L. F. T., Donzele, J. L., Gomes, P. C., Oliveira, R. F., Lopes, D. C., Ferreira, A. S., Barreto, S. L. T. \& Euclides, R. F. (2011). Tabelas Brasileiras para Aves e Suínos. 3.ed. Universidade Federal de Viçosa, Viçosa, Minas Gerais, 2011. 252p.

Silva, F. N. L., Medeiros, L. R., Lima, A. A. N., Xavier, D. T. O., Macedo, A. R. G., Reis, A. A., Brandão, L. V. \& Souza, R. A. L. (2017). Alimentos alternativos da agricultura familiar como proposta em ração para tambaqui (Colossoma macropomum). Pubvet, 11, $103-112$.

Teixeira, E. W. (1995). Utilização de alimentos fibrosos pelos suínos. Zootecnia, Nova Odessa, 33(1), 19-27.

Townsend, C. R., Costa, N., Pereira R. G. A., Senger, C. C. D. (2001). Características químico-bromatológica do caroço de açaí. Comunicado técnico. EMBRAPA-CPAF, Empresa Brasileira de Pesquisa Agropecuária Centro de Pesquisa Agroflorestal de Rondônia, (139), $2-5$.

Van Soest, P. J., Robertson, J. B. \& Lewis, B. A. (1991). Methods for dietary fiber, neutral detergent fiber, and nonstarch polysaccharides in relation to animal nutrition. Journal of Dairy Science, 74(10), 358-397.

Watanabe, P. H., Thomaz, M. C., Martins, M. I. E. G., Ruiz, U. S., Fraga, A. L., Santos, V. M., Pascoal, L. A. F. \& Silva. S. Z. (2009). Receitas bruta e líquida parcial e custo de dietas contendo polpa cítrica para suínos abatidos com 130kg de peso. Arquivo Brasileiro de Medicina Veterinária e Zootecnia, 61(1), 203210.

Willians, B. A., Verstegen, M. W. A. \& Tamminga, S. (2001). Fermentation in the large intestine of single-stomached animals and its relationship to animal health. Nutrition Research Review, 14, 207-227.

Woyengo, T. A., Beltranena, E. \& Zijlstra, R. T. (2014). Controlling feed cost by including alternative ingredients into pig diets: A review. Journal of Animal Science, 92, 1293-1305. 